\title{
Öğretmenlerin Örgütsel Sessizlik Algıları ile Okul Kültürü Algıları Arasındaki İlişki ${ }^{1}$
}

\author{
DOI: $10.26466 /$ opus. 875646 \\ $*$ \\ Betül Güngör * - Yüksel Gündüz ** \\ * Matematik Öğretmeni, Milli Eğitim Bakanlığı, Ordu/Türkiye \\ E-Posta: betulgungor1987@gmail.com ORCID: 0000-0002-8890-8624 \\ ** Doç. Dr., Ondokuz Mayıs Üniversitesi, Eğitim Fakültesi, Samsun, Türkiye \\ E-Posta: yukselgunduz0735@gmail.com ORCID: 0000-0002-4710-8444
}

\section{Öz}

Bu araştırmanın amacı, öğretmenlerin örgütsel sessizlik ile okul kültürü algıları arasındaki ilişkiyi ortaya koymaktır. Illişkisel tarama modelinde yapılan çalışmanın evrenini 2017-2018 eğitim öğretim yılında Ordu ili Fatsa ilçesinde görev yapan öğretmenler oluşturmaktadır. Tesadüfi örnekleme yöntemiyle belirlenen 587 öğretmen, araştırmanın örneklemini oluşturmuştur. Araştırmanın verileri, "örgütsel sessizlik ölçeği" ve "okul kültürü ölçeği" ile toplanmıştır. Verilerin analizinde yüzde, aritmetik ortalama, frekans, t-testi, ANOVA testi, Scheffe testi, basit ve çoklu regresyon teknikleri kullanılmıştır. Araştırma bulgularına göre, öğretmenlerin örgütsel sessizlik algılarının orta düzeyde olduğu saptanmıştır. Öğretmenlerin okul kültürü algılarının ise destek, görev ve başarı alt boyutlarında ortalamanın üstü, bürokratik kültür alt boyutunda ise orta düzeyde olduğu belirlenmiştir. Öğretmenlerin örgütsel sessizlik algılarında cinsiyet, yaş ve kıdem değişkenine göre anlaml farklılıklar bulunmamıştır. Branş ve okulda çalışma süresi değişkenlerine göre öğretmenlerin örgütsel sessizlik algılarında anlamlı farklılıklar görülmüş̧ür. Cinsiyet, yaş, branş, kıdem değişkenlerine göre öğretmenlerin okul kültürü algilarında anlaml farklılıklar görülmüştür. Okulda çalışma süresi değişkenine göre öğretmenlerin okul kültürrü algılarında anlamlı farklılıklar görülmemiştir. Öğretmenlerin örgütsel sessizlik algıları ile destek ve başarı kültürü alt boyutları arasında negatif yönde; bürokratik ve görev kültürü alt boyutları ile de pozitif yönde anlaml ilişki olduğu belirlenmiştir. Öğretmenlerin örgütsel sessizlik değişkeninin, okul kültürünün destek, başarı ve bürokratik alt boyutlarının anlamlı bir yordayıcısı olduğu saptanmiştır.

Anahtar Kelimeler: Öğretmen, Eğitim, Örgütsel Sessizlik, Okul Kültürü.

\footnotetext{
${ }^{1}$ Bu çalışma Betül GÜNGÖR'ün Doç. Dr. Yüksel GÜNDÜZ danışmanlığında hazırladığı yüksek lisans tezinden üretilmiştir.
}

OPUS @ U Uluslararası Toplum Araştırmaları Dergisi-International Journal of Society Researches ISSN:2528-9527 E-ISSN : 2528-9535

http://opusjournal.net 


\title{
The Correlation between Organizational Silence and School Culture Perceptions of Teachers
}

\begin{abstract}
The aim of this study is to reveal the relationship between teachers' perceptions of organizational silence and school culture. The universe of the study has conducted in the relational screening model consists of the teachers working in Fatsa district of Ordu in the 2017-2018 academic year. 587 teachers were determined by random sampling method has constituted the sample of the study. The data of the study has been collected by "organizational silence scale" and "school culture scale". Percentage, arithmetic mean, frequency, $t$-test, ANOVA test, Scheffe test, simple and multiple regression techniques have been used in the analysis of the data. According to the research findings, it has been determined that teachers' perceptions of organizational silence were at a moderate level. It has also been determined that teachers' perceptions of school culture are above average in the sub-dimensions of support, duty and success, and medium in the sub-dimension of bureaucratic culture. No significant differences have been found in teachers' perceptions of organizational silence according to the variables of gender, age and seniority. Significant differences have been observed in teachers' perceptions of organizational silence according to the variables of branch and school working time. Significant differences were observed in teachers' perceptions of school culture according to gender, age, branch, seniority variables. According to the variable of working time at school, there have been no significant differences in teachers' perceptions of school culture. It has been determined that there is a negative relationship between teachers' perceptions of organizational silence and the sub-dimensions of support and success culture also there is a positive significant relationship between bureaucratic and duty culture sub-dimensions. It has been observed that teachers' organizational silence variable is a significant predictor of the support, success and bureaucratic sub-dimensions of school culture.
\end{abstract}

Keywords: Teacher, Education, Organizational Silence, School Culture. 


\section{Giriş}

Eğitim sisteminin temel sistemi olan ve eğitim, öğretim faaliyetlerinin gerçekleştirildiği okullar, gelecek için büyük önem taşımaktadır. Okulların verimini artırmak için öğretmenlere büyük sorumluluk düşmektedir. Yöneticiler ise eğitimi sabote eden tüm faktörleri ortadan kaldırmak ve örgüt amaçlarına ulaşmak için ellerinden geleni yapmalıdırlar. Bunun için yönetici, öğretmenlerin okulda özgürce fikirlerini beyan edebilecekleri, eleştirel tutum sergileyebilecekleri ortamı sağlamalıdır. Öğretmenin düşüncelerini söylemekten çekindiği, kendini ifade etmekte zorlandığı durumlarda karşılaşılan en önemli engel sessizliktir. Sessizlik okul kültürüne dönüşürse, bu okulun geleceği açısından da ciddi olumsuz sonuçlar doğurur. Bu anlamda okul kültürü, örgütün amaçlarına ulaşmasında ve bu amaçlar uğruna çalışanların bağlllıklarının oluşmasında önemli işlevi üstlenmiştir. Sessizlik ve olumsuz okul kültürü örgüte dair istenmeyen sonuçlar doğurabilir; yenilenmeyi ve yaratıcllı̆ 1 engelleyebilir, öğrenmeyi yavaşlatabilir, sorunların farklı şekilde sonuçlanmasına sebep olabilir, güdülenmeyi azaltabilir, bireyin benlik saygısına zarar verebilir, psikolojik açıdan olumsuz etkileyebilir, kötümserliğe itebilir, örgüte bağlllı̆̆ 1 azaltabilir.

Örgütsel Sessizlik: Örgütsel sessizlik, bir kurumdaki çalışanların örgütlerine fayda sağlayabilme durumu varken, davranışsal, bilişsel ve duyuşsal düşüncelerini kasitlı olarak gizlemesi olarak tanımlanmaktadır (Pinder ve Harlos, 2001, s.334). Çalışanlar, herhangi bir soruna veya olaya ait bilgi ve düşüncelerini ifade ettiklerinde, durumun kötü sonuç doğuracağına inanmaktadır. Burada çalışanların, pozisyonlarını olumsuz anlamda etkileyeceği, sorun ç1karan biri gibi algılanabilecekleri, fikirlerinin herhangi bir değişikliğe etki etmeyeceğine dair inançları sessiz kalmalarında etkendir. Çalışanların çoğu diğer çalışanların önerilerini benimseyen, çoğunluğun fikrine uyumlu davranış göstermektedirler (Afşar, 2013, s.30; Çakıc1, 2008, s.118; Taşkıran, 2011, s.69). Kişi, ne yaparsam yapayım sonucu değiştiremeyeceğim düşüncesiyle gelecekte sonucu kontrol edecek bile olsa davranışı sergilemeyecektir (Bayat, 2002, s.4).

Sessizlik örgüt ve birey açısından istenmeyen durumlar doğarabilir . Sessizlik hareketlerinde örgüt, çalışanların yaratıcı fikirlerinden yoksun kalır. Bu 
durum örgütün gelişmesine ve yeniliklerle güncellenmesine engel olmaktadır. Çalışanlar kendileriyle ilgili bir sorunu veya endişelerini söylemekten çekinirler. Örgüte ve birbirlerine bağ konusunda sıkıntılar yaşarlar, kendini örgüte ait hissetmez, yönetici veya diğer çalışanlarla güven sorunları yaşar, motivasyonları azalır, gerek kendine gerek başkalarına karşı takdir etme/edilme ve destekleme/desteklenme duygularındaki tatminsizlik iş doyumunu azaltır bu durumlarda bazen örgütten ayrılmalar bile gerçekleşebilir (Barçın, 2012, s. 34). Örgüt içinde sessizliği kırmak ve kararlara katılımın sağlanması amacıyla herkesin fikirlerini rahatça ifade edebilecekleri bir güven ortamı hazırlanmalıdır. Çalışan sessizliğe kapılmadan, hiçbir endişe yaşamadan, kendini ifade edebilmelidir.

Örgütsel sessizlik, önceleri olumlu bir durum olarak algılanmaktaydı. Örgütteki çalışanların birbirleri ile ahenk ve uyum içinde çalıştıklarının bir göstergesi olarak görülmekteydi. Fakat günümüzde, örgütsel sessizlik hem örgüt hem birey için olumsuz bir durum olarak algılanmaktadır. Çalışanların bilinçli yaptıkları ve olaya karşı gösterdikleri bir tepki olarak sessiz kaldıkları bilinmektedir (Taşkıran, 2011, s.3). Sessizliği eskiden iyi niyetle karşılayan insanların çoğunlukla gerçekleştirdikleri ve üretkenliği artırdıklarına inandıkları bir olguydu. Hâlbuki sessizlik son derece yıkıcı sonuçlar doğurmaktadır. Kişiler anlaşmazlık durumlarında sessiz kaldıklarında, kaygı, öfke ve kızgınlık duyguları içerisine girmektedir. Bu duyguların bastırılması sonucu etrafına güvenmeyen, kendini korumaya alan ve düşündüklerini söylediklerinde utandırılarak reddedilmekten korkan kişiler haline gelirler. Güvensizliğin artması, daha fazla sessiz duruşlara, daha fazla savunmacılığa ve itimatsızlığa yol açar. Bu durum sessizlik sarmalını harekete geçirmektedir ve örgütsel boyutta sessizlik kısır döngüye dönüşmektedir (Perlow ve Williams, 2011, s.125). Sessizlik bu kısır döngüde, örgüt için faydalı yenilikleri ve örgüt gelişimini olumsuz etkilemektedir (Kahveci ve Demirtaş, 2013a, s.54).

Örgütlerde sessizleşmeye toplumun kültürel özellikleri sebep olabilmektedir. Taşkıran'a (2011) göre, bu kültürel özelliklerden biri güç mesafesidir. Güç mesafesi, çalışanların problem ve olaylara dair fikirlerini net bir şekilde sunmalarına engel olmaktadır. Bu güç mesafesinde bireylerin öneri ve düşüncelerini söylemeleri oldukça zordur. Ne yaparsam yapayım sonucu değiştiremeyeceğim şeklindeki geçmiş tecrübeler, kişinin önyargı ve alışkanlık kazanmasına sebep olmaktadır. Çünkü önceki yaşantısında istenilen sonuca 
ulaşmada etkisinin olmadığını gören ve davranışlarıyla sonucu kontrol edemeyeceğine inanan kişi, gelecekte sonucu kontrol edebilecek olsa da davranış ortaya koymayacaktır (Bayat, 2002, s.4). Bu durumu, öğrenilmiş çaresizlik olarak açıklayabiliriz. Öğrenilmiş çaresizlik, sessizliğe neden olan kültürel özelliklerden bir tanesidir. Bireyin sessizlik davranışını sergilemesinde bu kültürel temeller önemli rol oynamaktadır.

Sessizlik nedenlerini bireysel, örgütsel ve yönetsel faktörler olarak incelemek uygun görülmüştür. Sessizliğin bireysel nedenleri olarak, konuşmanin risk teşkil etmesi, kişinin karakteri, güvensizlik, sosyal açıdan dışlanma korkusu, geçmişte yaşanan tecrübeler, ilişkilere zarar verme korkusu ele alınmıştır. Örgütsel nedenleri olarak, örgütteki iklim, örgütteki adaletsizlik kültürü, örgütteki kültür ele alınmıştır. Yönetsel nedenler olarak, olumsuz geri bildirim korkusu, yöneticinin karakteri, yöneticinin çalışanlara olan önyargılı inanışları ele alınmıştır (Eroğlu, Adıgüzel ve Öztürk, 2011: 102).

Blackman ve Smith'e (2009) göre sessizlik, ne edilgenliği ne de baskınlı̆̆ ifade etmektedir. Sessizlik, ilk akla geldiği gibi boyun eğme ya da ezilmişlik de değildir. Anlaşılacağı üzere sessizlik düşünüldüğü gibi basit değil oldukça karmaşık bir kavramdır (aktaran, Kahveci, 2010, s.14). Sessizlik davranışlarının altında birçok sebep yatabileceği düşünülmelidir. Bu yüzden olay ve durumlara bütünsel olarak bakabilmek gerekmektedir. Bazı durumlarda, sessizlik örgüt ve çalışan için can kurtarıcı olabilmektedir. Çünkü bazı meseleler gündeme getirilmeye değmemektedir. Küçük görüş farklılıklarını dile getirmek, büyük anlaşmazlıklarla sonuçlanabilmektedir. Burada birey muhakeme yaparak, kendine bu konuşulması mı susulması mı gereken zamanlardan biri midir sorusunu sormalıdır (Perlow ve Williams, 2011, s.129).

Okul Kültürü: Örgüt kültürü, örgütleri birbirine bağlayan ve birbirlerinden özgün bir kimlik oluşturan, paylaşlan bir sistem bütünüdür (Hoy ve Miskel, 2010, s.165). Balcı'ya (2001) göre, örgüt kültürünün işlevselliği olumlu ve olumsuz olmak üzere incelenebilmektedir. İşlevsel özellikler: Örgütte çal1şanlara örgüt kimliği oluşturur, örgüt çalışanlarının örgüte olan bağlllıklarını artırır, örgütte sosyalizasyonu sağlar ve güçlendirir, örgütte çalışanların davranışlarını yönlendirip şekillendirerek anlamlar yükler ve denetim sağlamaya katkı yapar. İşlevsel olmayan özellikleri: Değişime ket vurarak tutuculuğu ve bağımlılığı artırır, örgütteki farklılıkları engelleyerek tek düze birey 
davranışları sergilemesine sebep olur, örgütsel birleşmelere engel olur. Örgüt kültürü çalışanlar üzerinde dolaylı ya da doğrudan etkileme gücüne sahiptir.

Örgüt kültürünün etkilerini şu şekilde sıralamak mümkündür: İş doyumu, çalışanlar arası iletişim, yönetim şekli, ast-üst ilişkileri, çalışma yöntemleri, örgütün başarısı ve verimi, çevreyle iletişim şekli, öğrenme istekleridir. Bunlar örgüt için son derece önemli konulardır. Bu yüzden örgüt kültürü üzerinde durulması gereken öncelikli konulardan biridir (Işık, 2006, s.2).

Okullarda da toplumlar gibi tek kültürden ziyade çeşitli alt kültürler hatta zıt kültürler de gelişebilmektedir. Bu açıdan bakıldığında yönetim kültürü, sendika kültürü, öğretmen kültürü, öğrenci kültürü, sınıf kültürü gibi kültürleri görmek mümkündür. Öğretmenler ve öğrencilerin kendi aralarında oluşabilecek daha ayrıntılı alt kültürlerden bahsedebilir. Örneğin, öğrenciler arasında var olan çeşitli gençlik kültürü gelişebilir. Okul kültürü, okul dışındaki çevrenin kültürüne göre alt kültürdür. Ancak okul içindeki çeşitli alt kültürlere göre ise baskın kültürdür. Dikkat edilmesi gereken bir husus da okul kültürü, okul kültüründe oluşan alt kültürlerin toplamıdır diyemeyiz. Okul kültürü, okuldaki bireylerin yaşanmışlıkları makro düzeyde paylaştıkları ortak kültürdür. Okulun en önemli durumu ise, bireyler arasında, bireylerle okul arasında bütünleşmeyi, paylaşımı sağlayabilmektir. Bunu sağlayabilmede kültür, bir tutkal görevi görmektedir (Şişman ve Turan, 2005, s.133). Okul kültürleri içindeki alt kültürlere bakıldığında, öğrenci alt kültürleri; ırk, sınıf, cinsiyet ve ilgiler etrafında şekillenebilir. Öğrenciler arasında var olan kültürel farklılıklar çatışmalara sebebiyet verebilir. Öğretmen alt kültürleri ise; cinsiyet, ırk, kıdem, mezun olunan okul etrafında şekillenebilir. Başarılı bir okul yöneticisi okulda var olan bu alt kültürler arasındaki farklılıkları kabullenmeli fakat bu alt kültürleri okulun güçlü değerleri ile birleştirebilmelidir (Terzi, 2000, s.106-107).

Okul kültürünü dört değişik biçimde incelemek yararlı olabilecektir. Birinci okul kültürü, başarısızlığın hâkim olduğu okul kültürüdür. Bu okulda çalışan yönetici, öğretmen ve öğrencilerde başarı beklentisi azdır ve bu tarz okullarda olumsuz semboller vardır. İkinci okul kültürü, başarının hâkim olduğu okul kültürüdür. Burada herkeste başarı beklentisi fazla ve başarı istenen bir durumdur. Bu okullarda onur köşeleri, madalyalar, gurur tabloları okulun sembollerini oluşturmaktadır. Üçüncü okul kültürü, insan kaynağ yetiştirmeyi amaçlayan ve hedefleyen okul kültürüdür. Okulun kültürel 
amaçlarında, insan kaynağ yetişmesi açık bir şekilde belirtilmiştir ve geliştirilmesi temel değerlerin en önemlilerindendir. Dördüncü okul kültürü, savaş niteliği taşımaktadır. Bu okul kültüründe, yöneticilerin iletişim biçimleri ve görünmeyen yönlerinden söz edilebilir. Bu kültürdeki her kural etrafa düşmanlık saçmaktadır. Okula yeni gelen her yönetici kısa sürede çökkünlük yaşamaktadır (Çelik, 2000, s.64).

Güçlü bir okul kültürü oluşturulması, yöneticilerin etkili ve verimli bir şekilde çalışmasını kolaylaştırabilir. Bu kapsamda okul kültürü oluşturabilmek için yöneticiler eğitim ve öğretimde insancıl değerler taşımalıdırlar. Yöneticiler, okul için kabullenilebilecek ve benimsenecek değerleri öğretmen-öğrenci ve çevreyle paylaşmalı nihayetinde ortak bir düşüncede buluşturmaya çalışmalıdır. Okulda efsaneleşmiş olan kişileri ve onların deneyimlerinin okul kültürü için önemli olduğunun farkına varmalıdır. İçinde yaşadığı toplumun değerlerinin, adetlerinin, geleneklerinin okul kültürü ile iç içe olmasını sağlamalıdır. Bu toplumun temel değerlerini ve adetlerini törenlerle destekleyerek işlemeli ve bu törenlerle yeni bir kültürün oluşmasına katkı sağlamalıdır. Okula yeni katılan kişilerin örgüt kültürüne uyumlarını sağlamalı ve rehberlik etmelidir. Okulda var olan farklı kültürler arasında dengeyi sağlamalı, herkesi ortak kültürde yapılandırmalıdır (Erdoğan, 2000, s.108-109). Bu kapsamda okul, kültür oluşumuna ve aktarımına yardımcı olmaktadır.

Okullar kültür aktarımının yapıldığı en önemli kurumlardır. Bu bağlamda okullarda var olan kültürü geliştirmek ve gerektiğinde değiştirmek toplumun yararı için vazgeçilmezdir. Bu nedenle, okullar gelecek nesillere kültür aktarımı yapan can damarlarımızdır denilebilir. Doğan'a (2017) göre, her okulun kendine özgü bir kültürü olması sebebiyle de toplumda çeşitlilik artmaktadır. Böylece, aynılaşmadan öte farklılaşma söz konusu olabilmektedir. Çünkü okulların en önemli görevlerinden biri, öğrencilerin özgün olabilmesini sağlamak ve başkası gibi değil, kendi gibi olmasına, kendini tanıması ve bulmasina rehber olabilmesidir.

Bugünün kültürü geçmiş nesillerin çabalarının ve tecrübelerinin eseri olup ve halen yaşayan insanların yaşantılarına göre sürekli değişmekte ve zenginleşmektedir. Yani kültür öğrenilen tavır ve davranışlar olup toplumun ortak yaşama şeklidir (Eroğlu, 2011, s.142). Okullar, toplumun her bireyini ilgilendiren, toplumsal kültürün aktarıldığı ve kültür ile iç içe olan kurumlardır. Erdem ve Kocabaş'a (2005) göre, eğitim sistemlerinde zaman zaman bazı modeller ve uygulamalar diğer toplumlardan direkt olarak değil toplumun 
kültürüne uyarlanarak alınmalıdır. Uyarlamak ise kendi toplumumuzun kültürüne uygun hale getirilmesidir. Ancak bu şekilde yapılırsa, etkililik ve verimlilikten söz edilebilir ve daha gerçekçi sonuçlar alınabilir. Güçlü ve etkili bir okul kültürü sayesinde, çalışanların verimi artar ve buna bağlı olarak öğrencilerin okula karşı ilgisi ve sevgisi artarak okula olan bağı güçlenir. Birbirini etkileyen bu durum, öğrencilerin akademik başarılarını üzerinde olumlu bir etkiye sahiptir (Dolunay, 2007, s.10).

Bu kapsamda yapılan araştırma sessizliği kırmak ve okul kültüründe yapılan yanlışları düzeltmek, geliştirmek adına yapılacak çalışmalara yol gösterici, yöneticilerin yaptıkları hataları düzeltmeleri adına bir kıvılcım olabilir. Diğer yandan, öğretmen ve yöneticilere bir farkındalık yaratarak bu sessizlik girdabından ve yanlış-eksik okul kültüründen kurtulma çabasına dair bir adımdır. Literatüre bakıldığında, örgütsel sessizlik ve okul kültürünün değişik bileşenlerle çalışıldığ görülmekte, ancak öğretmenlerin örgütsel sessizlik algıları ile okul kültürü algıları aralarındaki ilişkiye dönük çalışmanın ya hiç olmadığı ya da çok sınırlı olduğu düşünüldüğünde bu çalışma bu yöndeki boşluğu dolduracağı umulmaktadır.

\section{Çalışmanın Amacı}

$\mathrm{Bu}$ araştırmanın amacı, öğretmenlerin örgütsel sessizlik algıları ile okul kültürü algıları arasındaki ilişkiyi belirlemektir. Bu amaç doğrultusunda aşağıdaki sorulara yanıt aranmıştır:

1. Öğretmenlerin örgütsel sessizlik ve okul kültürü algıları ne düzeydedir?

2. Öğretmenlerin örgütsel sessizlik ve okul kültürü algıları cinsiyet, yaş, branş, kıdem, hizmet süresi değişkenlerine göre anlamlı farklılık göstermekte midir?

3. Öğretmenlerin örgütsel sessizlik algıları ile okul kültürü arasında anlamlı bir ilişki var mıdır?

4. Öğretmenlerin örgütsel sessizlik algıları, okul kültürü algılarının anlamlı yordayıcısı midır? 


\section{Yöntem}

\section{Araştırmanın Modeli}

Araştırma, öğretmenlerin örgütsel sessizlik algıları ile okul kültürü algıları arasındaki ilişkiyi belirlemeye yönelik olduğundan, araştırmada ilişkisel tarama modeli kullanılmıştır. İlişkisel tarama modeli, iki veya daha fazla değişkenler arasında birbiriyle ilişkili değişimin var olup olamadığını ve var ise bu değişimin ne düzeyde olduğunu belirlemeyi hedefleyen araştırma modelidir (Karasar, 1991, s.81).

\section{Evren ve Örneklem}

Araştırmanın evrenini, 2017-2018 eğitim öğretim yılında Ordu ili Fatsa ilçesinde bulunan 19 ilkokul, 20 ortaokul ve 12 lisede görevli 1257 öğretmen oluşturmaktadır. Araştırmanın örneklemini ise evrenden tesadüfi örnekleme yöntemi ile seçilen 587 öğretmen oluşturmaktadır. Bu örnekleme yönteminde, evrendeki tüm elemanları, eşit seçilme şansına sahiptirler (Büyüköztürk, Çakmak, Akgün, Karadeniz ve Demirel, 2013, s.85). Katılımcı grubun \% 54 'ü kadın , \% 46'sı ise erkektir. Yaş açısından öğretmen dağılımları incelendiğinde; \%35' inin 31-40 yaş arasında; \%29'unun 21-30 yaş arasında; \%26' sının 41-50 yaş arasında ve \%10'unun da 51 yaş ve üstü yaş aralığında oldukları saptanmıştır. Kıdem yılı açısından öğretmen dağılımları incelendiğinde; \%26' sının 21 yıl ve üstü aralığında; \%24'ünün 1-5 yıl aralığında; \%22'sinin 610 yıl aralığında; \%14'ünün 16-20 yıl aralığında ve \%14'ünün 11-15 yıl aralığında oldukları saptanmıştır. Görev yaptığı okuldaki hizmet süresi değişkeni açısından öğretmen dağılımları incelendiğinde; \%65'inin 1-5 yıl aralığında; \%21'inin 6-10 yıl aralığında ve diğer hizmet yılı kategorileri \% 10'nun altında oldukları saptanmıştır. Katılımcı grubun \%52' isi branş öğretmeni iken, \% 48'i sinuf öğretmenidir.

Veri Toplama Araçları: Bu araştırmada veri toplamak amacıyla " Kişisel Bilgi Formu" ve "Örgütsel Sessizlik Ölçeği" ile " Okul Kültürü Ölçeği” kullanılmıştır. Kişisel Bilgi Formu cinsiyet, yaş, kıdem, okuldaki hizmet süresi ve branş değişkenlerinden oluşmaktadır.

Örgütsel Sessizlik Ölçeği: Kahveci ve Demirtaş (2013b) tarafından geliştirilen ölçek 18 maddeden oluşmaktadır. Örgütsel sessizlik ölçeği okul ortamı 
(1-4. Maddeler), duygu (5-7. Maddeler), sessizliğin kaynağı (8-12. Maddeler), yönetici (13-15. Maddeler) ve izolasyon (16-18. Maddeler) olmak üzere beş alt boyuttan oluşmaktadır. Katılım dereceleri "Kesinlikle Katılmıyorum", "Katılmıyorum", "Kararsızım", "Katıllyorum" ve "Kesinlikle Katıllyorum" seçeneklerinden oluşmaktadır. Ölçeğin Cronbach's Alpha analizi sonucunda katsayıları okul ortamı için $\alpha=.74$, duygu için $\alpha=.81$, sessizliğin kaynağ için $\alpha=.80$, yönetici için $\alpha=.79$, izolasyon için $\alpha=.83$ 'tür. Ölçeğin geneli için güvenirlik katsayısı ise $\alpha=.89^{\prime}$ dur. Bu araştırmada Cronbach's Alfa katsayısı toplamda $\alpha=.89$ olarak bulunmuştur. Alt boyutlar için ise, yönetici için $\alpha=.77$, duygu için $\alpha=.75$, izolasyon için $\alpha=.81$, okul ortamı için $\alpha=.59$ ve sessizliğin kaynağı için $\alpha=.69^{\prime}$ dur.

Okul Kültürü Ölçeği: Terzi (2005) tarafindan geliştirilmiş olup, 29 maddeden oluşmaktadır. Okul kültürü ölçeği destek kültürü (8 madde), başarı kültürü (6 madde), bürokratik kültürü (9 madde) ve görev kültürü (6 madde) olmak üzere dört alt boyuttan oluşmaktadır. Katılım dereceleri "Hiçbir zaman", “Nadiren", "Bazen”, "Çoğunlukla” ve "Her zaman" seçeneklerinden oluşmaktadır. Ölçeğin Cronbach's Alpha analizi sonucunda katsayıları destek kültürü için $\alpha=.88$, başarı kültürü için $\alpha=.82$, bürokratik kültür için $\alpha=.76$, görev kültürü için $\alpha=.74$ 'tür. Ölçeğin geneli için güvenirlik katsayısı ise $\alpha=.84$ 'tür. Bu araştırmada Cronbach's Alfa katsayısı toplamda $\alpha=.85$ olarak bulunmuştur. Alt boyutlar için ise, destek kültürü için $\alpha=87$, başarı kültürü için $\alpha=.77$, bürokratik kültür için $\alpha=.75$ ve görev kültürü için ise $\alpha=.72$ ' dir.

\section{Verilerin Toplanması}

2017-2018 eğitim öğretim yılında Ordu ili Fatsa ilçesinde bulunan ilkokul, ortaokul ve liselerde çalışan her bir öğretmene iki ölçek verilmiş ve yanıtlamaları için yeterince zaman tanındıktan sonra, ölçekler toplanmıştır. Bu süreçte öğretmenler, 657 ölçeği doldurmuşlardır. Ancak tam doldurulmayan geçersiz ölçekler çıkarılarak, 587 ölçek geçerli kabul edilmiştir.

\section{Verilerin Analizi}

Elde edilen veriler SPSS 14,0 istatistik programı ile analiz edilmiştir. Verilerin analizinde, yüzde, frekans, aritmetik ortalama, standart sapma, bağımsız t- 
testi, ANOVA testi, post-hoc tekniklerden Scheffe veya tamhane çoklu karş1laştırma testi, pearson çarpım momentler korelasyon katsayısı, çoklu regresyon teknikleri kullanılmıştır.

\section{Bulgular}

Örgütsel sessizlik ölçeği toplam ve alt boyutları toplamlarının tanılayıcı istatistik değerleri Tablo 1'de sunulmuştur.

Tablo 1. Örgütsel Sessizlik Ölçeği Toplam ve Alt Boyutlarn Toplamlarnnn Tanılayıcı İstatistik Değerleri ( $N=587)$

\begin{tabular}{lll}
\hline Alt Boyutlar & & Ss \\
\hline Yönetici & 3.64 & .90 \\
Duygu & 3.58 & .87 \\
İzolasyon & 3.29 & .91 \\
Okul Ortamı & 3.31 & .71 \\
Sessizliğin Kaynağ & 3.07 & .72 \\
Toplam & 3.37 & .64 \\
\hline
\end{tabular}

Tablo 1 incelendiğinde, örgütsel sessizlik alt boyutlarına ilişkin en yüksek ortalama değeri yönetici ( $=3.64$ ) ve bunu sırasılyla, duygu $(=3.58)$, okul ortamı ( =3.31), izolasyon ( =3.29), sessizliğin kaynağı $(=3.07$ ) boyutları izlemektedir. Standart sapma değerleri incelendiğinde, en homojen dağılımın okul ortamı boyutunda ( $\mathrm{ss}=.71$ ), en heterojen dağılımın izolasyon boyutunda (ss=.91) gerçekleştiği görülmektedir. Başka bir ifadeyle, öğretmenlerin örgütsel sessizlik algılarının orta düzeyde (kararsızım) olduğu söylenebilir. Sessizliğin en yüksek olduğu boyut yönetici alt boyutu olmuştur.

Aşağıda, cinsiyet, yaş, branş, mesleki kıdem ve okuldaki hizmet süresi değişkenlerine göre, öğretmenlerin araştırma kapsamında kullanılan örgütsel sessizlik ölçeğine verdikleri yanıtların genel ve alt boyut puanları arasındaki farklılığa ilişkin bulgulara yer verilmiştir.

Öğretmenlerin örgütsel sessizlik algıları tüm ölçekte ve tüm alt boyutlarda cinsiyetlerine $[\mathrm{t}(585)=-.42, \mathrm{p}>.05]$, yaşlarına $[\mathrm{F}(3-58)=1.84$, $\mathrm{p}>.05]$ ve kıdemlerine $[\mathrm{F}(4-58)=.38, \mathrm{p}>.05]$, değişkenine göre anlamlı farklılık göstermemiştir. Aynı okuldaki çalışma süresi değişkenine göre, duygu alt boyutunda $[\mathrm{F}(4-$ $58)=5.34, p<.001]$ anlamlı bir farklılık bulunmuştur. ANOVA'da elde edilen farklılıkları belirlemek üzere; varyansların homojen olması nedeniyle post- 
hoc tekniklerden Scheffe testi kullanılmıştır. Okuldaki çalışma süresi 11-15 yıl arasında olanların örgütsel sessizlik ölçeği duygu alt boyut ortalaması ( =3.04), 1-5 yıl ( = 3.64), 6-10 yıl ( =3.56) ve 16-20 ( =3.85) yil arasında olan öğretmenlerden daha düşüktür. Sınıf ve branş öğretmenlerinin örgütsel sessizlik ölçeği sessizliğin kaynağı alt boyut ortalamaları arasında anlamlı farklılıklar bulunmuştur $[\mathrm{t}(585)=-2.11, \mathrm{p}<.05]$. Branş öğretmenlerinin sessizliğin kaynağını algılama düzeyleri, sınıf öğretmenlerinin algılarından daha yüksektir.

Okul kültürü ölçeği ve alt boyutları toplamlarının tanılayıcı istatistik değerleri Tablo 2' de sunulmuştur.

Tablo 2. Okul Kültürü Ölçeği Alt Boyutları Toplamlarının Tanılayıcı İstatistik Değerleri $(N=587)$

\begin{tabular}{lll}
\hline Alt Boyutlar & & Ss \\
\hline Destek Kültürü & 3.50 & .71 \\
Başar1 Külttürü & 3.61 & .67 \\
Bürokratik Kültür & 3.25 & .60 \\
Görev Külttürü & 3.94 & .58 \\
\hline
\end{tabular}

Tablo 2 incelendiğinde okul kültürü alt boyutlarına ilişkin en yüksek ortalama görev kültürü ( $=3.94$ ) ve bunu sırasıyla, başarı kültürü ( =3.61), destek kültürü ( =3.50), bürokratik kültür ( =3.25) izlemektedir. Standart sapma değerlerinde, en homojen dağılımın görev kültürü boyutunda (ss= .58), en heterojen dağılımın da destek kültürü boyutunda (ss=.71) gerçekleştiği görülmektedir. Başka bir ifadeyle, öğretmenlerin okul kültürü algıların, bürokratik kültür dışında ortalamanın üstü düzeyde (çoğunlukla) gerçekleştirdikleri söylenebilir. Bürokratik kültür algıları ise ortalama düzeydedir (bazen).

Aşağıda, cinsiyet, yaş, branş, mesleki kıdem ve okuldaki hizmet süresi değişkenlerine göre, öğretmenlerin araştırma kapsamında kullanılan okul kültürü ölçeğine verdikleri yanıtların genel ve alt boyut puanları arasındaki farkllığa ilişkin bulgulara yer verilmiştir.

Cinsiyet değişkenine göre, uygulanan t-testi sonucunda "destek kültürü" [t(585)= 2.50, p<.05], "başarı kültürü" [t(585)=2.47, p<.05] ve "görev kültürü" $[\mathrm{t}(585)=2.52, \mathrm{p}<.05]$ alt boyutlarında istatistiksel açıdan anlamlı bir farklılık meydana gelmiştir. Kadın öğretmenlerin okuldaki destek, başarı ve görev 
kültürü algıları, erkek öğretmenlerden anlamlı derecede daha yüksek$\operatorname{tir}(\mathrm{p}<.05)$. Bürokratik kültür alt boyutunda cinsiyet değişkeni açısından anlamlı farklılıklar görülmemiştir [t(585) $=1.06, \mathrm{p}>.05]$.

Yaş değişkeni açısından uygulanan ANOVA testine göre, destek kültürü $[\mathrm{F}(3-58)=1.82, \mathrm{p}>.05]$, başarı kültürü $[\mathrm{F}(3-58)=1.84$, $\mathrm{p}>$.05] ve bürokratik kültür alt boyutlarında anlamlı bir farklılık görülmezken, görev kültürü boyutunda görülmüştür. Anlamlı farklılı̆̆ belirlemek amacıyla uygulanan scheffe testi sonucunda yaş değişkenine göre görev kültürü alt boyutunda $41-50$ ve 51 yaş ve üstü olan öğretmenlerin puan ortalamaları, 21-30 yaştan anlamlı derecede daha yüksektir $(\mathrm{p}<.05)$. Diğer taraftan 51 yaş ve üstü olan öğretmenlerin görev kültürünü algılamaları, 31-40 yaş grubundan anlamlı derecede daha yüksek seviyededir $(\mathrm{p}<.05)$.

Branş değişkenine göre, uygulanan t- testi sonucunda okul kültürü, bürokratik kültür alt boyutunda $[\mathrm{t}(585)=.10, \mathrm{p}>.05]$ anlamlı bir farklılık oluşmazken, "destek" [t(585)=5.27, p<.001], "başarı" [t(585)=3.96, p<.001] ve "gö$\operatorname{rev}^{\prime \prime}[\mathrm{t}(585)=4.16, \mathrm{p}<.001]$ kültürü alt boyutlarında istatistiksel açıdan anlamlı farklılıklar oluşmuştur. Bu farklılıkların tümü sınıf öğretmenleri lehine gerçekleşmiştir.

Kıdem değişkenine göre, ANOVA testinde elde edilen farklılıkları belirlemek amacıyla uygulanan scheffe testi sonucunda kıdemi 21 yıl ve üstü öğretmenlerin destek kültürü algıları, 6-10 yıl arasında olan öğretmenlerden anlamlı derecede daha yüksektir ( $\mathrm{p}<$.05). Yine 21 yıl ve üstü öğretmenlerin okul başarı kültürü algıları, 6-10 yıl arasında olan öğretmenlerden anlamlı derecede daha yüksektir ( $\mathrm{p}<.05)$. Kıdemi 21 yıl ve üstü öğretmenlerin okul bürokratik kültürü algıları, 1-5 yıl arasında olan öğretmenlerden anlamlı derecede daha yüksektir $(\mathrm{p}<.05)$. Aynı şekilde kıdemi 21 yıl ve üstü öğretmenlerin okul görev kültürü algilarl; 1-5 yıl ( $p<.05), 6-10$ yıl ( $p<.05)$ ve 11-15 yıl ( $p<.05)$ olanlardan anlamlı derecede daha yüksektir. Diğer ikili karşılaştırmalar arasında istatistiksel açıdan anlamlı farklılıklar bulunamamıştır.

Öğretmenlerin okul kültürü algıları, okulda çalışma süresilerine göre, uygulanan ANOVA testinde destek $[\mathrm{F}(4-58)=1.71, \mathrm{p}>.05]$, başarı $[\mathrm{F}(4-58)=1.16$, $\mathrm{p}>$.05] bürokratik $[\mathrm{F}(4-58)=1.32$, p>.05] ve görev $[\mathrm{F}(4-58)=3.83$, $\mathrm{p}<.01]$, kültürleri için anlamlı bir farklılık elde edilememiştir.

Örgütsel sessizlik ve okul kültürü ölçekleri alt boyutları arasındaki ilişkiler Tablo 3'de gösterilmiştir. 
Tablo 3. Örgütsel Sessizlik ve Okul Kültürü̈ Ölçeği Toplam ve Alt Boyutlarnna İlişkin Korelasyon Katsayılarn $(\mathrm{N}=587)$

\begin{tabular}{|c|c|c|c|c|c|c|c|c|c|c|}
\hline & 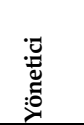 & 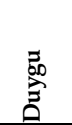 & 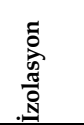 & $\begin{array}{l}\text { 志 } \\
\text { ț } \\
\text { o }\end{array}$ & 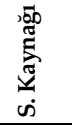 & 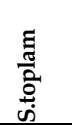 & 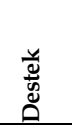 & 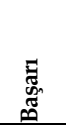 & 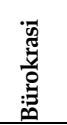 & 总 \\
\hline S.yönetici & 1 & & & & & & & & & \\
\hline S.duygu & $.45^{* * *}$ & 1 & & & & & & & & \\
\hline S.izolasyon & $.54^{* * *}$ & $.55^{* * * *}$ & 1 & & & & & & & \\
\hline S.okul ortamı & $.45^{* * *}$ & $.61^{* * *}$ & $.49^{* * *}$ & 1 & & & & & & \\
\hline S.kaynağı & $.56^{* * *}$ & $.48^{* * *}$ & $.53^{* * * *}$ & $.45^{* * *}$ & 1 & & & & & \\
\hline S.toplam & $.78^{* * *}$ & $.79^{* * * *}$ & $.813^{* * * *}$ & $.75^{* *}$ & $.76^{* * *}$ & 1 & & & & \\
\hline K.destek & $-.15^{* * *}$ & $-.27^{* * *}$ & $.22^{* * *}$ & $-.30^{* *}$ & $-.18^{* * *}$ & $-.29 * * *$ & 1 & & & \\
\hline K.başarı & $-.17^{* * * *}$ & $-.27^{* * *}$ & $.21^{1 * * *}$ & $-.29 * *$ & $-19^{* * * *}$ & $-.29 * * *$ & $.80^{0 * * *}$ & 1 & & \\
\hline K.bürokrasi & $.28^{* * *}$ & $.28^{* * *}$ & $.24^{* * *}$ & $.34^{* * *}$ & $.33^{* * *}$ & $.37^{* * * *}$ & $-.12^{* * *}$ & -.06 & 1 & \\
\hline K.görev & .07 & .02 & .06 & .07 & .04 & .07 & $.37 * * *$ & $.43^{* * *}$ & $.24^{* * *}$ & 1 \\
\hline
\end{tabular}

Örgütsel sessizlik toplam ve alt boyutlarında en yüksek .81 (p<.05), en düşük .76 $(\mathrm{p}<.05)$ arasında istatistiksel açıdan anlamlı pozitif ilişkiler bulunmuştur. Bu durum ölçeğin bu çalışmada da yapı geçerliğinin bir kanıtı olmuştur.

Okul kültürü ölçeğinden bir toplam puan elde edilmemektedir. Bu nedenle ölçeğin alt boyutları ile toplam arasında bir korelasyona bakılamamıştır. Fakat ölçeğin alt boyutları arasında korelasyon katsayıları elde edilmiştir. Destek kültürü ile başarı kültürü arasında pozitif yönde anlamlı bir ilişki bulunmuştur (r: .80). Destek kültürü içinde yine pozitif yönde anlamlı bir ilişki vardır (r: .37). Fakat destek kültürü ile bürokratik kültür arasında negatif yönde anlamlı bir ilişki söz konusudur. Başarı kültürü ile görev kültürü arasında pozitif yönde anlamlı bir ilişki varken, bürokratik kültür arasında anlamlı bir ilişki yoktur. Bürokratik kültür ile görev kültürü arasında pozitif yönde (r: .243) anlamlı bir ilişki söz konusudur.

Örgütsel sessizlik toplam puanlarından, okul kültürü ölçeği alt boyut puanlarını yordamak üzere sonuçlar Tablo 4-5-6-7'de gösterilmiştir.

Tablo 4. Örgütsel Sessizlik Toplam/Destek Kültürü Toplamına İlişkin Regresyon Analizi Sonuçlar

\begin{tabular}{|c|c|c|c|c|c|}
\hline Değişken & B & s. $\mathbf{H}$ & B & $t$ & $\mathrm{p}$ \\
\hline İçerik & 4.57 & .15 & & 30.76 & $.00^{* * *}$ \\
\hline Örgütsel Sessizlik Toplam & -.32 & .04 & -.290 & -7.32 & $.00^{* * *}$ \\
\hline
\end{tabular}


Örgütsel sessizlik, destek kültürü ile negatif yönde anlamlı bir ilişki vermektedir. $\mathrm{R}=.29, \mathrm{R}^{2}=.08, \mathrm{p}<0.05$. Örgütsel sessizlik, destek kültüründeki varyansının \%8,4'ünü açıklamaktadır. Regresyon katsayısının anlamlılığına ilişkin bağımsız $\mathrm{t}$ - testi sonuçları incelendiğinde ise, $(\mathrm{t}=-7.32, \mathrm{p}=.00)$ örgütsel sessizliğin, destek kültürünün anlamlı bir yordayıcısı olduğu görülmektedir. Öğretmenlerin örgütsel sessizlik algıları arttıç̧a birbirlerine güven azalabilir buna bağlı olarak dayanışma da azaldığı için öğretmenlerin destek kültürü algiları azalabilir.

Tablo 5. Örgütsel Sessizlik Toplam/Başan Kültürü Toplamına İlişkin Regresyon Analizi Sonuçlarn

\begin{tabular}{|c|c|c|c|c|c|}
\hline Değişken & B & s.H & $\beta$ & $T$ & p \\
\hline İçerik & 4.63 & .14 & & 32.70 & $.00^{* * *}$ \\
\hline Örgüt sessizlik Toplam & -.30 & .04 & -.29 & -7.39 & $.00^{* * *}$ \\
\hline
\end{tabular}

Örgütsel sessizlik, başarı kültürü ile negatif yönde anlamlı bir ilişki vermektedir. $\mathrm{R}=.29, \mathrm{R}^{2}=.09, \mathrm{p}<0.05$. Örgütsel sessizlik, başarı kültüründeki varyansının \%8.5'ini açıklamaktadır. Regresyon katsayısının anlamlılığına ilişkin bağımsız $t$-testi sonuçları incelendiğinde ise, $(t=-7.39, p=.00)$ örgütsel sessizliğin, başarı kültürünün anlamlı bir yordayıcısı olduğu görülmektedir.

Tablo 6. Örgütsel Sessizlik Toplam/Bürokratik Kültür Toplamına İlişkin Regresyon Analizi Sonuçlarn

\begin{tabular}{llllll}
\hline Değişken & B & s.H & $\beta$ & $\mathbf{T}$ & $\mathbf{p}$ \\
\hline İçerik & 2.06 & .12 & & 16.53 & .00 \\
Örgüt sessizlik Toplam & .35 & .04 & .37 & 9.76 & .00 \\
\hline
\end{tabular}

$R=.37 \quad R^{2}=.14 \quad F=95.18 \quad p=.00$

Örgütsel sessizlik, bürokratik kültür ile pozitif yönde anlamlı bir ilişki vermektedir. $\mathrm{R}=.37, \mathrm{R}^{2}=.14, \mathrm{p}<0.05$. Örgütsel sessizlik, bürokratik kültürü varyansının \%14'ünü (regresyon analizi çoklu stepwise yöntemiyle yapılmıştır. enter yöntemi değildir tezden uyarlama olduğundan yapılacak değişiklikler veri kaybına sebep olacaktır. diğer tablolarda da aynı durum sözkonusudur) açıklamaktadır. Regresyon katsayısının anlamlılığına ilişkin bağımsız t-testi sonuçları incelendiğinde ise, $(t=9.76, p=.00)$ örgütsel sessizliğin, bürokratik kültürün anlamlı bir yordayıcısı olduğu görülmektedir. 
Tablo 7. Örgütsel Sessizlik Toplam/Görev Kültürü Toplamına İlişkin Regresyon Analizi Sonuçlan

\begin{tabular}{|c|c|c|c|c|c|}
\hline Değişken & B & s.H & $\beta$ & $t$ & $p$ \\
\hline İçerik & 3.73 & .13 & & 29.17 & .00 \\
\hline Örgüt sessizlik Toplam & .06 & .04 & .07 & 1.74 & .08 \\
\hline
\end{tabular}

Örgütsel sessizlik, görev kültürü ile pozitif yönde anlamlı bir ilişki vermektedir. $\mathrm{R}=.07, \mathrm{R}^{2}=.01, \mathrm{p}>.05$. Regresyon katsayısının anlamlılığına ilişkin bağımsız $t$-testi sonuçları incelendiğinde ise, $(t=1.74, p=.08)$ örgütsel sessizliğin, görev kültürünün anlamlı bir yordayıcısı olmadığı görülmektedir.

Örgütsel sessizlik alt boyutlarının, okul kültürü alt boyutlarını yordamak üzere dört ayrı çoklu regresyon analizi sonuçları Tablo 8-9-10-11'de verilmiştir.

Tablo 8. Örgütsel Sessizlik Alt Boyutlarn/Destek Külttürüne İlişkin Çoklu Regresyon Analizi Sonuçları

\begin{tabular}{llllll}
\hline Değişken & \multicolumn{2}{l}{$\begin{array}{l}\text { Standart olmayan } \\
\text { regresyon katsayısı }\end{array}$} & $\begin{array}{l}\text { Standart regres- } \\
\text { yon katsayısı }\end{array}$ & $\mathbf{t}$ & $\mathbf{p}$ \\
\hline (İçerik) & $\mathbf{B}$ & $\mathbf{s . H}$ & $\boldsymbol{\beta}$ & & \\
Okul ortamı & 4.64 & .15 & & 30.52 & .00 \\
Duygu & -.21 & .05 & -.22 & -4.13 & $.00^{* * *}$ \\
Sessizliğin kaynağı & -.10 & .04 & -.12 & -2.18 & $.03^{*}$ \\
Yönetici & -.02 & .05 & -.02 & -.32 & .75 \\
İzolasyon & .03 & .04 & .04 & .71 & .478 \\
\hline
\end{tabular}

Bağımlı değişken: Destek kültürü

Örgütsel sessizlik, öğretmenlerin destek kültürü ile negatif yönde anlamlı ilişkiler vermektedir. Bütün örgütsel sessizlik alt boyutları ile destek kültürü arasındaki çoklu korelasyon katsayısı $\mathrm{R}=.33, \mathrm{R}^{2}=.12$ 'dir.

Regresyon katsayılarının anlamlılığına ilişkin bağımsız t- testi sonuçları incelendiğinde, sadece okul ortamı ve duygu alt boyutlarının, destek kültürünün anlamlı bir yordayıcısı olduğu görülmektedir. Örgütsel sessizlik okul ortamı alt boyutu, tek başına destek kültürü varyansının \% 9.5' ini, duygu alt boyutu ise \% 1.2' sini açıklamıştır. Bu iki değişkenin birlikte varyansı açılama yüzdesi 10.7 olmuştur. Örgütsel sessizlik sessizliğin kaynağı, yönetici ve izolasyon alt boyutlarının tek başına destek kültürü varyansını açıklama 
yüzdesi yeterli değildir ve yapılan bağımsız t-testinde istatistiksel açıdan anlamlı bir sonuç vermemiştir.

Tablo 9. Örgütsel Sessizlik Alt Boyutlar/Başan Külttürüne İlişkin Çoklu Regresyon Analizi Sonuçları

\begin{tabular}{llllll}
\hline Değişken & $\begin{array}{l}\text { Standart olmayan regresyon } \\
\text { katsayıs }\end{array}$ & $\begin{array}{l}\text { Standart regresyon } \\
\text { katsayısı }\end{array}$ & $\mathbf{t}$ & $\mathbf{p}$ \\
\hline (Içerik) & 4.70 & .15 & & 32.28 & .00 \\
Okul ortamı & -.19 & .05 & -.20 & -3.75 & $.00^{* * * *}$ \\
Duygu & -.09 & .04 & -.12 & -2.12 & $.04^{*}$ \\
Sessizliğin kaynağı & -.03 & .05 & -.03 & -.65 & .52 \\
Yönetici & .01 & .04 & .02 & .29 & .77 \\
İzolasyon & -.03 & .04 & -.05 & -.87 & .38 \\
\hline
\end{tabular}

Bağımlı değişken: Başarı kültürü

Örgütsel sessizlik alt boyutları, öğretmenlerin başarı kültürü ile negatif yönde anlamlı ilişkiler vermektedir. Bütün örgütsel sessizlik alt boyutları ile başarı kültürü arasındaki çoklu korelasyon katsayısı $\mathrm{R}=.32, \mathrm{R}^{2}=.10$ ‘dir.

Regresyon katsayılarının anlamlılığına ilişkin bağımsız $\mathrm{t}$ - testi sonuçları incelendiğinde, sadece okul ortamı ve duygu alt boyutlarının, başarı kültürü üzerinde anlamlı bir yordayıcısı olduğu görülmektedir. Örgütsel sessizlik okul ortamı alt boyutu, tek başına başarı kültürü varyansının \% 8.9'unu, duygu alt boyutu ise \% 1.2'sini açıklamıştır. Bu iki değişkenin birlikte varyansı açıklama yüzdesi 10.2 olmuştur. Örgütsel sessizlik ölçeğinin sessizliğin kaynağı, yönetici ve izolasyon alt boyutlarının tek başına okul başarı kültürü değişkeninin varyansını açıklama düzeyi yeterli değildir ve yapılan bağımsız t-testinde istatistiksel açıdan anlamlı bir sonuç vermemiştir.

Örgütsel sessizlik alt boyutları, bürokratik kültür ile pozitif yönde anlamlı ilişkiler vermektedir. Bütün örgütsel sessizlik alt boyutları ile bürokratik kültür arasındaki çoklu korelasyon katsayısı $R=.40, R^{2}=16$ ‘dir.

Regresyon katsayılarının anlamlılığına ilişkin bağımsız $\mathrm{t}$ - testi sonuçları incelendiğinde, sadece okul ortamı ve sessizliğin kaynağı alt boyutlarının, bürokratik kültür alt boyutu üzerinde anlamlı bir yordayıcısı olduğu görülmektedir. Örgütsel sessizlik ölçeği okul ortamı alt boyutu, tek başına bürokratik kültür varyansının \% 11.2'sini sessizliğin kaynağı alt boyutu ise \% 3.9'unu açıklamıştır. Bu iki değişkenin birlikte varyansı açılama yüzdesi 15.1 olmuştur. 
Tablo 10. Örgütsel Sessizlik Alt Boyutlarn/Bürokratik Kültüre İlişkin Çoklu Regresyon Analizi Sonuçlan

\begin{tabular}{llllll}
\hline Değişken & \multicolumn{2}{l}{$\begin{array}{l}\text { Standart olmayan reg- } \\
\text { resyon katsayısı }\end{array}$} & $\begin{array}{l}\text { Standart regresyon } \\
\text { katsayısı }\end{array}$ & $\mathbf{t}$ & $\mathbf{p}$ \\
\hline & $\mathbf{B}$ & $\mathbf{s . H}$ & $\mathbf{B}$ & & \\
\hline (İçerik) & 1.93 & .13 & & 15.14 & .00 \\
Okul ortamı & .18 & .04 & .21 & 4.06 & $.00^{* * *}$ \\
Duygu & .04 & .04 & .06 & 1.07 & .29 \\
Sessizliğin kaynağı & .16 & .04 & .19 & 3.74 & $.00^{* * *}$ \\
Yönetici & .05 & .03 & .07 & 1.46 & .15 \\
İzolasyon & -.02 & .03 & -.03 & -.59 & .56 \\
\hline
\end{tabular}

Bağımlı değişken: Bürokratik kültür

Tablo 11. Örgütsel Sessizlik Alt Boyutlarn/Görev Kültürüne İlişkin Çoklu Regresyon Analizi Sonuçlarn

\begin{tabular}{llllll}
\hline Değişken & \multicolumn{2}{l}{$\begin{array}{l}\text { Standart olmayan regresyon } \\
\text { katsayıs }\end{array}$} & $\begin{array}{l}\text { Standart regres- } \\
\text { yon katsayısı }\end{array}$ & $\mathbf{t}$ & $\mathbf{p}$ \\
\hline \multicolumn{1}{c}{$\mathbf{B}$} & $\mathbf{s . H}$ & $\boldsymbol{\beta}$ & & \\
\hline (İçerik) & 3.71 & .13 & & 28.01 & .00 \\
Okul ortamı & .06 & .05 & .07 & 1.35 & .18 \\
Duygu & -.04 & .04 & -.06 & -1.07 & .29 \\
Sessizliğin kaynağı & .00 & .04 & .00 & .02 & .98 \\
Yönetici & .03 & .04 & .05 & .85 & .40 \\
İzolasyon & .02 & .04 & .03 & .60 & .55 \\
\hline
\end{tabular}

Bağımlı değişken: Görev kültürü

Örgütsel sessizlik ölçeği duygu, yönetici ve izolasyon alt boyutlarının tek başına okul bürokratik kültür alt boyutunun varyansını açıklama yüzdesi yeterli değildir ve yapılan bağımsız t-testinde istatistiksel açıdan anlamlı bir sonuç vermemiştir.

Örgütsel sessizlik ölçeği alt boyut değişkenleri, öğretmenlerin algiladığ1 bürokratik okul kültürü ile anlamlı ilişkiler vermemektedir. Bütün örgütsel sessizlik alt boyutları ile bürokratik kültür arasındaki çoklu korelasyon katsayıs $\mathrm{R}=.10, \mathrm{R}^{2}=.01^{\prime}$ dir.

Regresyon katsayılarının anlamlılığına ilişkin bağımsız $\mathrm{t}$ - testi sonuçları incelendiğinde, örgütsel sessizliğin alt boyutlarının okul görev kültürünün anlamlı bir yordayıcısı olmadığı görülmektedir. 


\section{Sonuç, Tartışma ve Öneriler}

Öğretmenlerin örgütsel sessizlik algıları orta düzeyde (kararsızım) olmuştur. Oysa sessizlik algısının daha alt düzeylerde olması beklenirdi. Bu düzeydeki sessizlik algısının işgören ve örgüt açısından bir takım dezavantajlı sonuçlar doğurması olasıdır. Bu sonuç Daşcı (2014), Yangın (2015) ve Dönmez (2016) tarafından yapılan çalışma sonuçları ile örtüşmektedir. Ancak Yenel (2016), Yüksel (2014), Kolay (2012) ve Kahveci'nin (2010) aynı yöndeki araştırma sonuçları ile örtüşmemektedir. Bu farklılıklar sessizliğin yaşantılara, ortama ve yaşanan yıllara bağlı değişebileceğini göstermektedir.

Öğretmenlerin yönetici alt boyutlu sessizlik algılarınn duygu, okul ortamı, izolasyon ve sessizliğin kaynağı alt boyutlarından daha yüksek olduğu tespit edilmiştir. Bu sonuç, Nartgün ve Kartal (2013), Daşc (2014) ve Dönmez'in (2016) yaptığı çalışmaların sonuçlarıyla örtüşürken, Aydın'ın (2016) yaptığı çalışmanın sonucu ile örtüşmemektedir. Bu durum, öğretmenlerin yöneticiye güvenmemeleri ve yöneticinin adil olmayan tutumlarından kaynaklanmış olabilir. Örgütsel sessizlik en yüksek düzeyde yönetici alt boyutunda gerçekleştiğinden yöneticilere etkin iletişim becerileri konusunda eğitim verilmesinin oldukça yararı görülebilir.

Öğretmenlerin yönetici alt boyutlu sessizlik algilarının ortalamanın üstü düzeyde (katıllyorum); duygu, okul ortamı, izolasyon ve sessizliğin kaynağ alt boyut sessizlik algılarının orta düzeyde (kararsızım) olduğu belirlenmiştir. Nartgün ve Kartal'ın (2013) yaptığı çalışmada öğretmenlerin örgütsel sessizlik algılarının izolasyon alt boyutunda orta düzeyde olduğu tespit edilmiştir. Bu araştırmanın sonucu ile örtüşmektedir.

Öğretmen örgütsel sessizlik ölçeği toplam ve alt boyutlarının hiçbirinde cinsiyet değişkenine göre anlamlı bir farklılık bulunmamıştır. Bu sonuç, Nartgün ve Kartal (2013), Yüksel (2014), Yangın'ın (2015) yaptığı çalışmaların sonuçları ile uyumludur. Ancak Aydın (2016), Dönmez (2016) ile Kahveci ve Demirtaş (2013a) tarafından yapılan çalışmaların sonucuyla uyumlu değildir.

Öğretmen örgütsel sessizlik ölçeği toplam ve alt boyutlarının hiçbirinde yaş değişkenine göre anlamlı bir farklılık olmadığı belirlenmiştir. Yüksel (2014) ve Yangın'ın (2015) öğretmenlerin örgütsel sessizlik algıları üzerinde yaptığı çalışmalarda da yaş değişkenine göre anlamlı farklılık bulunmamış- 
tır. Fakat Aydın'ın (2016) yaptığı çalı̧̧mada ise öğretmenlerin örgütsel sessizlik alt boyutlarının her biri ile yaş değişkeni arasında anlamlı farklılıklar bulunmuştur.

Öğretmenlerin örgütsel sessizlik algılarının sadece sessizliğin kaynağı alt boyutunda branş değişkenine göre anlamlı farklılıklar bulunmuştur. Branş öğretmenlerinin sessizliğin kaynağını algılama düzeylerinin, sını öğretmenlerinin düzeylerinden daha yüksek olduğu belirlenmiştir. Kahveci ve Demirtaş'ın (2013a) yaptığı çalışmada öğretmenlerin sessizlik algıları yönetici ve okul ortamı alt boyutlarında branş değişkenine göre anlamlı farklılık bulunmuştur. Yangın'ın (2015) çalışmasında ise, branş değişkenine göre anlamlı farklılık bulunmamıştır. Bu çalışma ile sonuçlar örtüşmemektedir.

Öğretmen örgütsel sessizlik ölçeği toplam ve alt boyutlarının hiçbirinde kıdem değişkenine göre anlamlı bir farklılık olmadığı belirlenmiştir. Bu sonuç, Kolay (2012), Nartgün ve Kartal (2013) ve Dönmez'in (2016) araştırma sonuçları ile benzerlik göstermektedir. Ancak Aydın'ın (2016) aynı yöndeki çalışması ile benzerlik göstermemektedir.

Öğretmenlerin örgütsel sessizlik algilarının sadece duygu alt boyutunda okulda çalışma süresi değişkenine göre anlamlı farklılıklar bulunmuştur. Burada 11-15 yıl aralığında çalışan öğretmenlerin duygu alt boyutlu örgütsel sessizlik algılarının 1-5 yıl, 6-10 yıl ve 16-20 aralığında çalışan öğretmenlere göre daha düşük olduğu belirlenmiştir. Bu sonuç, Kolay (2012), Kahveci ve Demirtaş (2013a), Nartgün ve Kartal (2013) ve Dönmez' in (2016) aynı yönde yaptığı araştırma sonuçlarıyla örtüşmemektedir.

Öğretmenlerin okul kültürü algilarının en yüksek düzeyde olan alt boyutu görev kültürüdür (çoğunlukla). Bunu sırasıyla başarı, destek ve bürokratik kültür takip etmektedir. Görev, başarı ve destek kültürü alt boyutları ortalamanın üstü düzeyde (çoğunlukla), bürokratik kültür alt boyutunun ise orta düzeyde (bazen) olduğu belirlenmiştir. Sezgin (2010), Özdemir (2012) ve Işık'ın (2017) öğretmenler üzerinde yaptığı okul kültürü algılarını belirlemek için gerçekleştirdiği çalışmada en yüksek alg1 görev kültürü alt boyutunda, sonra başarı kültürü, daha sonra destek kültürü ve en düşük algı ise bürokratik kültür olarak saptanmıştır. Sonuçlar bu araştırmanın sonucu ile örtüşmektedir. Görev kültürün yüksek çıkması öğretmenlerin amaçları doğrultusunda işinin gerektirdiklerini layıkıyla yapmaya önem verdiklerinin göster- 
gesi olabilir. Destek ve başarı kültürünün ortalamanın üstü çıkması öğretmenler arasında yardımlaşma ve iletişimin güçlü olmasından ayn zamanda okulun hedeflerinin başarı odaklı olmasından kaynaklanıyor olabilir.

Öğretmenlerin okul kültürü algılarının destek, başarı ve görev alt boyutlarında cinsiyet değişkenine göre anlamlı farklılıklar bulunmuştur. Kadın öğretmenlerin okuldaki destek, başarı ve görev kültürü algılarının, erkek öğretmenlerden daha yüksek olduğu tespit edilmiştir. Terzi'nin (2005) çalışmasında öğretmenlerin cinsiyete göre görev kültürü alt boyutlarında anlamlı farklılık saptanmıştır. Bu sonuç, araştırmanın sonucu ile örtüşmektedir. Yurttakal (2007) ve Işık'ın (2017) yaptığı çalışmada ise cinsiyete göre hiçbir alt boyutta istatistiksel olarak anlamlı farklılık bulunmamıştır. Bu araştırmanın sonucu ile örtüşmemektedir. Tanrı̈ğgn, Baştürk ve Başer (2014) ve Kaya'nın (2015) çalışmalarında göre destek ve başarı kültürü alt boyutlarında anlamlı farklar bulunmuştur. Bu araştırmanın sonucu ile örtüşmektedir.

Öğretmenlerin okul kültürü algilarının sadece görev kültürü alt boyutunda yaş değişkenine göre anlamlı farklılıklar bulunmuştur. 41-50 ve 51 yaş ve üstü aralığında bulunan öğretmenlerin görev kültürü algılarının 21-30 yaş aralığındaki öğretmenlere göre daha yüksek olduğu belirlenmiştir. Ayrıca 51 yaş ve üstü olan öğretmenlerin görev kültürü algılarının 31-40 yaş aralığındaki öğretmenlerden daha yüksek olduğu belirlenmiştir. Işık'ın (2017) yaptığı çalışmanın sunucu bu sonuçla örtüşmektedir.

Okul kültürü algılarının destek, başarı ve görev kültürü alt boyutlarında branş değişkenine göre istatistiksel açıdan anlamlı farklılıklar elde edilmiştir. Sınıf öğretmenlerinin destek, başarı ve görev kültürü algilarının branş öğretmenlerininkinden daha yüksek olduğu belirlenmiştir. Bu sonuç, Kaya'nın (2015) araştırma sonucu ile benzerlik gösterirken, Yurttakal'ın (2007) araştırma sonucu ile benzerlik göstermemektedir.

Okul kültürü ölçeğinin tüm alt boyutlarında kıdem değişkenine göre anlamlı farklılıklar elde edilmiştir. Kıdemi 21 yıl ve üstü öğretmenlerin destek kültürü ve başarı kültürü algıları, 6-10 yıl arasında olan öğretmenlerden anlamlı derecede daha yüksektir. Kıdemi 21 yıl ve üstü öğretmenlerin okul bürokratik kültürü algıları, 1-5 yıl arasında olan öğretmenlerden anlamlı derecede daha yüksektir. Aynı şekilde kıdemi 21 yıl ve üstü öğretmenlerin okul görev kültürü algıları; 1-5 yıl, 6-10 yıl ve 11-15 yıl olanlardan anlamlı derecede daha yüksek olduğu tespit edilmiştir. Terzi'nin (2005) çalışmasında da benzer 
sonuçlar elde edilmiştir. Ancak, Kaya (2015) ve Yurttakal'ın (2007) yaptığı çalışmanın sonuçları benzerlik göstermemektedir.

Okul kültürü ölçeğinin alt boyutlarının hiçbirinde okuldaki hizmet süresi değişkenine göre istatistiksel açıdan anlamlı farklılıklar elde edilememiştir. Işık'ın (2017) yaptığı çalışmada ise, okuldaki hizmet süresi başarı kültürü alt boyutunda anlamlı ilişki olduğu saptanmıştır. Bu araştırmanın sonucu ile örtüşmemektedir.

Öğretmenlerin örgütsel sessizlik algıları ile destek ve başarı kültürü alt boyutları arasında negatif yönde, bürokratik ve görev kültürü alt boyutları ile pozitif yönde anlamlı ilişki olduğu belirlenmiştir. Örgütsel sessizlik değişkeninin; okul kültürü destek, başarı ve bürokratik alt boyutları değişkenleri üzerinde anlamlı bir yordayıcı olduğu tespit edilmiştir. Öğretmen örgütsel sessizlik algılarının okul ortamı ve duygu alt boyutu değişkenlerinin okul destek kültürü ve okul başarı kültürü değişkenleri üzerinde anlamlı bir yordayıcı olduğu belirlenmiştir. Öğretmen örgütsel sessizlik algılarının okul ortamı ve sessizliğin kaynağı alt boyutu değişkenlerinin okul bürokratik kültürü değişkeni üzerinde anlamlı bir yordayıcı olduğu belirlenmiştir. Öğretmenler okuldaki yanlışlara ve aksaklıklara sessiz kaldıkları sürece karşılaşılan problemlerde çözüme ulaşmada sıkıntılar yaşanabilir. Dolayısıyla öğretmenlerin sessizlik düzeyinin artması problemlerin çözümünü ve başarı kültürünü olumsuz etkilediği söylenebilir. Okul yöneticilerinin otoriter tavrı öğretmenlerin sessiz kalmalarında büyük etken olabilir. Yöneticilerin gereksiz evrak işlerine, güç gösterisine karşı öğretmenlerin sessiz tutumları okuldaki bürokratik kültür algılarının artmasına etken olduğu söylenebilir. Öğretmenlerin okulun ortamına uyum sağlamaları ve olayları kişiselleştirmelerinden dolayı sessiz kalmaları, okulda birbirleriyle dayanışma içerisinde olmalarını engellemektedir diyebiliriz.

Örgütün gelişmesi ve varlığını devam ettirebilmesi için örgütsel sessizliğin neden ve sonuçlarını aynı zamanda okul kültürünün niteliklerini saptamak adına, daha kapsamlı nitel çalışmalar yapılabilir. Özellikle sessizliğin çok yönlü olmasından, anlaşılması ve yorumlanmasının da zor olmasından dolayı görüşme tekniği kullanılarak sessizliğin nedenleri daha derinlemesine incelenebilir. 


\title{
EXTENDED ABSTRACT
}

\section{The Correlation between Organizational Silence and School Culture Perceptions of Teachers}

\author{
Betül Güngör - Yüksel Gündüz \\ Ondokuz Mayıs University
}

The culture of the teachers and the school has important effects on the achievement of the aims of educational institutions and their survival in a healthy way. Teachers develop their behavior in accordance with the culture of the school. In a well-formed school culture, teachers should be able to express their opinions easily. However, the most important obstacle in cases where the teacher hesitates to express his or her thoughts and cannot express him- or herself is silence. If silence turns into a school culture, this will have serious negative consequences for the future of the school. In this sense, school culture plays an important role in achieving the goals of the organization and in the formation of commitment in the employees for these goals. Silence and a negative school culture can have many unwanted consequences for the school, such as reduced motivation, growth of problems, slow learning, and hindering innovation and creativity.

Organizational silence is defined as the deliberate hiding of behavioral, cognitive and affective thoughts of employees in an institution which have the capacity to improve their organization (Pinder and Harlos, 2001, p.334). Important factors in remaining silent are the beliefs and thoughts that the employees' current positions will be affected negatively, that they may be perceived as a problematic person, and that their suggestions or thoughts will not cause any change. In addition, the thought of not being able to change the outcomes will lead the person not to show a behavior even if it could have changed the future (Bayat, 2002, p.4).

Organizational culture is a shared system that holds organizations together and gives them a distinctive identity from each other (Hoy ve Miskel, 2010, s.165). Organizational culture has a positive effect on job satisfaction, communication between employees, management style, subordinate-superior relations, working methods, the organization's success and efficiency, communication style with the environment, and learning 
requests (Işık, 2006, p.2). The organizational culture has functional features such as creating an organizational identity for the employees of the organization, increasing the commitment of the employees towards the organization, directing and shaping the behavior of the employees in the organization and providing control. It also has non-functional features such as increasing conservatism and dependency by preventing change, preventing monotonous behavior and organizational mergers by preventing differences in the organization (Balc1, 2001).

In this context, the aim of the study is to reveal the relationship between teachers' perceptions of organizational silence and school culture. In this sense, the answers to the following questions were sought.

1. What is the level of teachers' perception of organizational silence?

2. Do teachers' perceptions of organizational silence differ significantly according to gender, age, branch, seniority, and period of service?

3. What is the level of teachers' perception of school culture?

4. Do teachers' perceptions of school culture differ significantly according to the variables of gender, age, branch, seniority, and period of service?

5. Is there a significant relationship between teachers' perceptions of organizational silence and school culture?

6. Are teachers' perceptions of organizational silence a significant predictor of school culture perception?

\section{Method}

The research is designed as a relational scanning model. The population of the research consists of 1257 teachers working in 43 different public schools in the 2017-2018 academic year in Fatsa, Ordu. The sample of the study consists of 587 teachers selected from the universe by random sampling method. The data were collected using a personal information form, "Organizational Silence Scale" and "School Culture Scale". In the analysis of data percentage, arithmetic mean, t-test, ANOVA test, pearson product moments correlation coefficient, and multiple regression techniques were used. 


\section{Results}

In the study, it was observed that teachers' perceptions of organizational silence were at a medium level. It was seen that teachers' perceptions of organizational silence did not show significant differences in the total and sub-dimensions of the scale according to the variables of gender, age and seniority. It was determined that teachers' perceptions of organizational silence showed significant differences in the source of silence sub-dimension according to the branch variable and in the emotion sub-dimension according to the variable of period of service at school. It was determined that teachers' perceptions of school culture are above average in the subdimensions of support, duty and success, and at a medium level in the sub-dimension of bureaucratic culture. It was observed that teachers' perceptions of school culture created significant differences in the sub-dimensions of support, achievement and duty according to the gender and branch variable, and also in the duty culture sub-dimension according to the age variable. Significant differences were obtained in the teachers' perceptions in all sub-dimensions of the school culture scale according to of the variable of seniority. None of the teachers' perceptions of school culture showed significant differences according to the variable of period of service at school. It was determined that there was a relationship between teachers' perceptions of organizational silence and the sub-dimensions of support and success culture in a negative direction, and a positive significant relationship with the bureaucratic and duty culture sub-dimensions. It was found that the teacher organizational silence variable is a significant predictor on the variables of support, achievement and bureaucratic subdimensions of school culture. Furthermore, it was determined that the school environment and emotion sub-dimension variables of teachers organizational silence perceptions were significant predictors of school support culture and school achievement culture variables. It was determined that teacher organizational silence perceptions' sub-dimension variables of school environment and source of silence are significant predictors of school bureaucratic culture variable. 


\section{Conclusion}

In the study, it was determined that teachers' perceptions of organizational silence were at a medium level. It was determined that teachers' perceptions of school culture were above average in the sub-dimensions of support, duty and success, and at a medium level in the sub-dimension of bureaucratic culture. It was determined that there was a negative relationship between teachers' perceptions of organizational silence and the sub-dimensions of support and success culture, and a positive significant relationship with the bureaucratic and duty culture sub-dimensions. It has been determined that the teacher organizational silence variable is a significant predictor of the support, achievement and bureaucratic sub-dimensions of school culture.

\section{Kaynakça / References}

Afşar, L. (2013). Örgütsel sessizlik ve örgütsel güven ilişkisi: Konuya ilişkin bir araştrrma. Yayınlanmamış Yüksek Lisans Tezi. İstanbul Üniversitesi, Sosyal Bilimler Enstitüsü: İstanbul.

Aydın, F. (2016). Ortaokul yöneticilerinin kullandıkları örgütsel güç türleri ve öğretmenlerin örgütsel sessizlik dauranışları. Yayınlanmamış Yüksek Lisans Tezi. Pamukkale Üniversitesi, Eğitim Bilimleri Enstitüsü: Denizli.

Bala, A. (2001). Etkili okul ve okul geliştirme. Ankara: Pegem A Yayınclık.

Barçın, N. (2012). İşletmelerde örgütsel sessizliğin örgütsel bağlllık ve iş tatminine etkisi üzerine bir araştırma. Yayınlanmamış Yüksek Lisans Tezi. Çukurova Üniversitesi, Sosyal Bilimler Enstitüsü: Adana.

Bayat, B. (2002). Örgütlerde güdülenme yetersizlikleri ve geri çekilme-kaçınma davranışlarını açıklamakta kullanılabilecek bir model: Öğrenilmiş çaresizlik. Gazi Üniversitesi I.I.I.B.F. Dergisi, 4(3), 1-14.

Büyüköztürk, Ş., Çakmak, E., Akgün, Ö. E., Karadeniz, Ş. ve Demirel, F. (2013). Bilimsel araştrma yöntemleri. Ankara: Pegem Akademi.

Çakıcı, A. (2008). Örgütlerde sessiz kalınan konular, sessizliğin nedenleri ve algılanan sonuçları üzerine bir araştırma. Ç.Ü. Sosyal Bilimler Enstitüsü Dergisi, 17(1), $117-134$.

Çelik, V. (2000). Okul kültürü ve yönetimi. Ankara: Pegem A Yayınları. 
Daşc, E. (2014). Illköğretim kurumu yöneticilerinin liderlik tarzları ile öğretmenlerin yaşadıkları (mobbing) ve örgütsel sessizlik davranışları arasındaki ilişki. Yayınlanmamış Yüksek Lisans Tezi. Gazi Üniversitesi, Eğitim Bilimleri Enstitüsü: Ankara.

Doğan, S. (2017). Okul kültürü ve iklimi. (Ed: C. T. Uğurlu), Okul Yönetimi (s.91-119). İstanbul: Anı Yayıncilık.

Dolunay, S. K. (2007). Okul kültürü ve Türkçe öğretimi. Türkiye Sosyal Araştırmalar Dergisi, 11(3), 9-22.

Dönmez, E. (2016). Örgütsel sosyalleşme ile örgütsel sessizlik arasındaki ilişki. Yayınlanmamış Yüksek Lisans Tezi. Pamukkale Üniversitesi, Eğitim Bilimleri Enstitüsü: Denizli.

Erdem, R. ve Kocabaş, İ. (2005). Eğitim denetçilerinin kültürel değerleri. Fırat Üniversitesi Sosyal Bilimler Dergisi, 15(2), 199-207.

Erdoğan, İ. (2000). Okul yönetimi ve öğretim liderliği. İstanbul: Sistem Yayıncılık.

Eroğlu, A. H., Adıgüzel, O. ve Öztürk, U. C. (2011). Sessizlik girdabı ve bağlılık ikilemi: İşgören sessizliği ile örgütsel bağlılık ilişkisi ve bir araştırma. Süleyman Demirel Üniversitesi İktisadi ve İdari Bilimler Fakültesi Dergisi, 16(2), 97-124.

Eroğlu, F. (2011). Davranış bilimleri. İstanbul: Beta Yayıncılık.

Hoy, W. and Miskel, C. (2010). Eğitim yönetimi. (S. Turan, Çev.) İstanbul: Nobel Yayın Dağıtım.

Işık, A. N. (2006). Örgüt kültürünün bazı değişkenlere göre analizi (Ĕ̆itim fakültesi örneği). Yayınlanmamış Yüksek Lisans Tezi. Selçuk Üniversitesi, Sosyal Bilimler Enstitüsü: Konya.

Işık, H. (2017). Ortaokullarda okul kültürünün incelenmesi. İstanbul Aydın Üniversitesi Dergisi, 35, 61-71.

Kahveci, G. (2010). İlköğretim okullarnnda örgütsel sessizlik ile örgütsel bağhllı arasındaki ilişkiler. Yayınlanmamış Yüksek Lisans Tezi. Fırat Üniversitesi, Sosyal Bilimler Enstitüsü: Elazı̆̆.

Kahveci, G. ve Demirtaş, L. (2013a). Okul yöneticisi ve öğretmenlerin örgütsel sessizlik algiları. Eğitim ve Bilim, 38(167), 50-64.

Kahveci, G. ve Demirtaş, Z. (2013b). Öğretmenler için örgütsel sessizlik ölçeği geliştirme çalışması. Elektronik Sosyal Bilimler Dergisi, 12(43), 167-182.

Karasar, N. (1991). Bilimsel araştırma yöntemi (4. b.). Ankara: Nobel Yayın Dağıtım.

Kaya, Ö. Y. (2015). Örgüt kültürü ve örgütsel vatandaşlık davranışı ilişkisi (Balıkesir ili Merkez ilçe örneği). Yayınlanmamış Yüksek Lisans Tezi. Balıkesir Üniversitesi, Sosyal Bilimler Enstitüsü: Balıkesir. 
Kolay, A. (2012). Endüstri meslek liselerinde görev yapan öğretmenlerin örgütsel sessizlik ve örgütsel bağhlliklar arasindaki ilişki. Yayınlanmamış Yüksek Lisans Tezi. Yeditepe Üniversitesi, Sosyal Bilimler Enstitüsü: İstanbul.

Nartgün, Ş. ve Kartal, V. (2013). Öğretmenlerin örgütsel sinizm ve örgütsel sessizlik hakkındaki görüşleri. Bartın Üniversitesi Ĕ̆itim Fakültesi Dergisi, 2(2), 47-67.

Özdemir, S. (2012). İlköğretim okullarında okul kültürü ile örgütsel sağllk arasındaki ilişki. Kuram ve Uygulamada Eğitim Yönetimi [Educational Administration: Theory and Practice, 18(4), 599-620.

Perlow, L. and Williams, S. (2011). Sessizlik şirketinizi öldürüyor mu? Etkin iletişim (İ. Gülfidan, (2014), Çev., s.123-140). İstanbul: MESS Yayınları.

Pinder, C. C. and Harlos, K. P. (2001). Employee silence. Research in Personnel and Human Resources Management, 20, 331-369.

Sezgin, F. (2010). Öğretmenlerin örgütsel bağlllığının bir yordayıcısı olarak okul kültürü. Eğitim ve Bilim, 35(156), 142-159.

Şişman, M. ve Turan, S. (2005). Eğitim ve okul yönetimi. (Ed: Y. Özden), Ĕ̆itim ve okul yöneticiliği el kitabı (s.99-146). Ankara: Pegem A Yayıncllk.

Tanriöğen, Z. M., Baştürk, R. ve Başer, M. (2014). İlköğretim okullarında cinsiyet ve örgütsel rollere göre örgüt kültürü algısı. Trakya Üniversitesi Eğitim Fakültesi Dergisi, 4(1), 170-180.

Taşkıran, E. (2011). Liderlik ve örgütsel sessizlik arasındaki etkileşim. İstanbul: Beta Yayınları.

Terzi, A. R. (2000). Örgüt külttürü. Ankara: Nobel Yayın Dağıtım.

Terzi, A. R. (2005). İlköğretim okullarında örgüt kültürü. Kuram ve Uygulamada Eğitim Yönetimi,43, 423-442.

Yangin, D. (2015). Etkileşim adaleti ve yöneticiye güven ile öğretmenlerin örgütsel sessizlik davramışları arasındaki ilişki. Yayınlanmamış Yüksek Lisans Tezi. Ondokuz Mayıs Üniversitesi, Eğitim Bilimleri Enstitüsü: Samsun.

Yenel, K. (2016). İlkokul yöneticilerinin dönüşümcü ve işlemci liderlik biçimleri ile öğretmenlerin örgütsel vatandaşlı ve örgütsel sessizlik davranıslan arasındaki ilişki. Yayınlanmamış Yüksek Lisans Tezi, Gazi Üniversitesi, Eğitim Bilimleri Enstitüsü: Ankara.

Yurttakal, S. (2007). Illköğretim öğretmenlerinin okullarmı örgüt kültürü açısından algılamalarn (Şırnak ili İdil ilçesi örneği). Yayınlanmamış Yüksek Lisans Tezi. Pamukkale Üniversitesi, Sosyal Bilimler Enstitüsü: Denizli.

Yüksel, R. F. (2014, Aralık). Okul çalışanlarnnn örgütsel bağhllık ve örgütsel sessizlik düzeyleri arasındaki ilişkilerin incelenmesi. Yayınlanmamış Yüksek Lisans Tezi. Okan Üniversitesi, Sosyal Bilimler Enstitüsü: İstanbul. 


\section{Kaynakça Bilgisi / Citation Information}

Güngör, B. ve Gündüz, Y. (2021). Öğretmenlerin örgütsel sessizlik algılar1 ile okul kültürü algıları arasındaki ilişki. OPUS-Uluslararası Toplum Araştırmaları Dergisi, 18(40), 2586-2614. DOI: 10.26466/ opus. 875646 . 